03

\title{
Зажигание борсодержащих высокоэнергетических материалов на основе окислителя и полимерного связующего
}

\author{
(C) А.Г. Коротких, ${ }^{1,2}$ И.В. Сорокин, ${ }^{1}$ К.В. Слюсарский, ${ }^{1}$ В.А. Архипов ${ }^{2}$ \\ ${ }^{1}$ Национальный исследовательский Томский политехнический университет, \\ 634050 Томск, Россия \\ ${ }^{2}$ Национальный исследовательский Томский государственный университет, \\ 634050 Томск, Россия \\ e-mail: korotkikh@tpu.ru
}

Поступило в Редакцию 28 ноября 2020 г.

В окончательной редакции 22 января 2021 г.

Принято к публикации 25 января 2021 г.

Использование боридов алюминия является перспективным направлением развития современных топливных композиций и летательных аппаратов. Представлены экспериментальные данные кинетики окисления микроразмерных порошков алюминия, аморфного бора, боридов алюминия $\mathrm{AlB}_{2}$ и $\mathrm{AlB}_{12}$ в воздухе при нагреве с постоянной скоростью $10^{\circ} \mathrm{C} / \mathrm{min}$, а также результаты лазерного зажигания высокоэнергетических материалов на основе перхлората аммония, нитрата аммония, инертного и активного горючих-связующих, содержащих указанные порошки металлов. Установлено, что применение борсодержащих порошков позволяет снизить значения температур начала и интенсивного окисления, увеличить их полноту окисления по сравнению с чистым алюминием. Полученные зависимости времени задержки зажигания от плотности теплового потока показали, что наиболее эффективным металлическим горючим являются порошки $\mathrm{AlB}_{2}$ и $\mathrm{AlB}_{12}$ в составе топлива на основе перхлората аммония, нитрата аммония и активного горючего-связующего, с точки зрения снижения времени задержки зажигания и подводимого потока тепла.

Ключевые слова: высокоэнергетический материал, алюминий, бор, борид алюминия, окисление, зажигание, энергия активации, время задержки зажигания.

DOI: 10.21883/JTF.2021.06.50861.329-20

\section{Введение}

Порошки металлов являются высокоэнергетическими компонентами современных смесевых твердых и гибридных топлив [1], используемых в твердотопливных ракетных двигателях и летательных аппаратах. Наиболее распространенным металлическим горючим в высокоэнергетических материалах (ВЭМ), используемых в аэрокосмической промышленности, является порошок алюминия разной дисперсности [2]. В настоящее время актуальным вопросом является возможность повышения теплоты сгорания ВЭМ за счет использования борсодержащих компонентов. Удельная теплота сгорания бора составляет $58.1 \mathrm{MJ} / \mathrm{kg}$ [3], что значительно превышает значение теплоты сгорания алюминия $(31 \mathrm{MJ} / \mathrm{kg})[3,4]$. Однако при нагреве и воспламенении частиц бора на поверхности образуется плотный оксидный слой $\mathrm{B}_{2} \mathrm{O}_{3}$ [5], который препятствует полному окислению частиц бора при относительно низких температурах. Теоретический прирост массы при полном окислении бора составляет около 218\%. В термическом анализе при нагреве порошка бора в кислороде до температуры $1000^{\circ} \mathrm{C}$ увеличение массы бора составляет $\sim 140 \%$ [6], а при нагреве в воздухе до $1500^{\circ} \mathrm{C}$ прирост массы бора составляет $\sim 160 \%$ [7]. Таким образом, в реакцию окисления вступает не более 75 и 82 mass.\% от исходной массы бора соответственно.
Использование различных сплавов на основе $\mathrm{Al}-\mathrm{B}$ (бориды алюминия) [8-10] или механической смеси алюминий/бор в различных соотношениях [11-13] является перспективным решением преодоления недостатков порошков бора и алюминия. Использование боридов алюминия в качестве горючих компонентов ВЭМ является актуальным в связи с разработкой новых двигательных установок летательных аппаратов. Данные металлические горючие имеют высокую плотность $2.50-2.84 \mathrm{~g} / \mathrm{cm}^{3}$, удельную теплоту сгорания $43-54 \mathrm{MJ} / \mathrm{kg}$ [3] на уровне бора. Кроме того, в работах [12-14] показано, что бориды алюминия обладают лучшей реакционной способностью в процессе их нагрева и горения, из-за наличия в них алюминия, бора, а также отсутствия огнеупорного слоя оксида алюминия $\mathrm{Al}_{2} \mathrm{O}_{3}$ на поверхности частиц. Использование боридов алюминия может найти широкое применение в высокоэнергетических составах, поскольку степень окисления $\mathrm{AlB}_{2}$ составляет $\sim 80 \%$ при степени окисления исходных порошков бора $\sim 20 \%$ и алюминия $\sim 67 \%$ [15]. Значения удельной теплоты сгорания боридов металлов на 40-70\% выше теплоты сгорания чистого алюминия [3]. Кроме того, в работе [16] экспериментально определено, что полнота сгорания составов на основе перхлората калия и политетрафторэтилена с наноразмерным порошком $\mathrm{AlB}_{2}$ на 5-20\% выше, чем для состава с микроразмерным порошком диборида 
Таблица 1. Исследуемые составы ВЭМ

\begin{tabular}{|c|c|c|c|c|c|}
\hline \multirow{2}{*}{$\begin{array}{c}\text { Состав } \\
\text { ВЭМ }\end{array}$} & \multicolumn{4}{|c|}{ Содержание компонентов, mass.\% } & \multirow[b]{2}{*}{$\alpha^{*}$} \\
\hline & $\begin{array}{c}\text { ПХА, } \\
\text { (размер, } \mu \mathrm{m})\end{array}$ & $\begin{array}{c}\text { НА, } \\
(\text { размер, } \mu \mathrm{m})\end{array}$ & Связуюшее & Металл, марка & \\
\hline $1-1$ & $69.0(165-315,<50)$ & - & 16.0, СКДМ-80 & 15.0, $\mathrm{Al}$ & 0.50 \\
\hline $1-2$ & $74.0(165-315,<50)$ & - & 11.0, СКДМ-80 & $15.0, \mathrm{~B}$ & 0.50 \\
\hline $1-3$ & $71.4(165-315,<50)$ & - & 13.6, СКДМ-80 & $15.0, \mathrm{AlB}_{2}$ & 0.50 \\
\hline $1-4$ & $73.2(165-315,<50)$ & - & 11.8, СКДМ-80 & $15.0, \mathrm{AlB}_{12}$ & 0.50 \\
\hline $2-1$ & $21.3(165-315)$ & $49.8(50-100)$ & 13.9, СКДМ-80 & $15.0, \mathrm{Al}$ & 0.50 \\
\hline $2-2$ & $22.5(165-315)$ & $52.5(50-100)$ & 10.0, СКДМ-80 & $15.0, \mathrm{~B}$ & 0.48 \\
\hline $2-3$ & $21.9(165-315)$ & $51.3(50-100)$ & 11.8, СКДМ-80 & $15.0, \mathrm{AlB}_{2}$ & 0.50 \\
\hline $2-4$ & $22.5(165-315)$ & $52.5(50-100)$ & 10.0, СКДМ-80 & $15.0, \mathrm{AlB}_{12}$ & 0.50 \\
\hline $3-1$ & $15.0(160-315)$ & $35.0(<100)$ & 20.0, МПВТ-АСП & $30.0, \mathrm{Al}$ & 0.66 \\
\hline $3-2$ & $18.0(160-315)$ & $42.0(<100)$ & 25.0, МПВТ-АСП & $15.0, \mathrm{~B}$ & 0.65 \\
\hline $3-3$ & $15.6(160-315)$ & $36.4(<100)$ & 23.0, МПВТ-АСП & $25.0, \mathrm{AlB}_{2}$ & 0.57 \\
\hline $3-4$ & $17.7(160-315)$ & $40.3(<100)$ & 25.0, МПВТ-АСП & $17.0, \mathrm{AlB}_{12}$ & 0.63 \\
\hline
\end{tabular}

Примечан и е. * $\alpha$ - коэффициент избытка окислителя.

алюминия. Также отметим, что при взаимодействии Ті и Al с бором выделяется большое количество энергии, обеспечивающее основу для процесса самораспространяющегося высокотемпературного синтеза (CBC) при получении боридов [17-18].

Целью настоящей работы является определение параметров процесса окисления микроразмерных порошков алюминия, аморфного бора и боридов алюминия $\left(\mathrm{AlB}_{2}\right.$ и $\left.\mathrm{AlB}_{12}\right)$ на основании экспериментальных данных термического анализа, а также установление закономерностей зажигания и влияния бора в составах ВЭМ на время задержки зажигания при лучистом подводе тепла.

\section{1. Материалы и методика исследования}

\section{1. Составы ВЭМ}

В изготовлении смесевых составов ВЭМ использовались микроразмерные порошки алюминия (средний диаметр частиц $d_{43}=10.8 \mu \mathrm{m}$ ), аморфного бора $\left(d_{43}=2.0 \mu \mathrm{m}\right)$ и боридов алюминия $\mathrm{AlB}_{2}\left(d_{43}=6.2 \mu \mathrm{m}\right)$, $\mathrm{AlB}_{12}\left(d_{43}=2.3 \mu \mathrm{m}\right)$, которые получали СВС методом в инертной среде (НИИ ПММ ТГУ). Путем смешения в заданном соотношении компонентов Al и В с последующим их прессованием на гидравлическом прессе получали цилиндрические образцы, которые помещались в CBC-реактор с аргоном. Спеченные в ходе СВС образцы металлов размельчались в шаровой мельнице в течение 30 минут. С использованием рентгеновского дифрактометра Shimadzu XRD-6000B в готовом продукте порошков контролировался фазовый состав боридов алюминия, который соответствовал массовому соотношению алюминия и бора в $\mathrm{AlB}_{2}$ - 55.5 mass.\% $\mathrm{Al}$ и 44.5 mass.\% B, в $\mathrm{AlB}_{12}$ - 17.2 mass.\% $\mathrm{Al}$ и 82.8 mass.\% В [3].

В исследование характеристик зажигания смесевых составов ВЭМ использовались три компонентных со- става ВЭМ (табл. 1), содержащих перхлорат аммония (ПХА) и бутадиеновый каучука марки СКДМ-80 (состав 1), ПХА, нитрат аммония (НА) и СКДМ-80 (состав 2), ПХА, НА и метилполивинилтетразол марки МПВТ-АСП (состав 3).

\section{2. Экспериментальные установки}

В исследовании закономерностей окисления порошков металлов в воздухе использовался совмещенный ТГ-ДСК анализатор Netzsch STA 449 F3 Jupiter. В анализе применялись керамические тигли, в которые засыпалась навеска порошка металла массой 5-8 mg. Нагрев образцов порошка металла осуществлялся в печи от 30 до $1200^{\circ} \mathrm{C}$ с постоянной скоростью нагрева печи $10^{\circ} \mathrm{C} / \mathrm{min}$ и объемным расходом воздуха $150 \mathrm{ml} / \mathrm{min}$.

Определение основных характеристик зажигания смесевых составов ВЭМ осуществляли на экспериментальном стенде, включающем непрерывный $\mathrm{CO}_{2}$-лазер РЛС-200 с длиной волны излучения $10.6 \mu \mathrm{m}$ и максимальной мощностью $200 \mathrm{~W}$, блок электропитания, системы охлаждения и регистрации параметров зажигания. Диаметр лазерного луча на выходе из полупрозрачного зеркала $\mathrm{CO}_{2}$-лазера был примерно равен диаметру образца. Образцы ВЭМ, содержащие порошки металлов, диаметром 10 и высотой $30 \mathrm{~mm}$ изготавливали методом проходного прессования с последующим отверждением в сушильном шкафу, которые перед опытом нарезались в виде таблеток высотой $5 \mathrm{~mm}$. Плотность отвержденных образцов ВЭМ составляла $1.76-1.78 \mathrm{~g} / \mathrm{cm}^{3}$. Описание работы экспериментальной установки представлено в работе [10]. Время задержки зажигания $t_{\text {ign }}$ состава ВЭМ определяли по разности электрических сигналов фотодиодов, регистрирующих времена начала инициирования образца (открытия электромагнитного затвора) и появления пламени вблизи поверхности топлива. В опытах варьировались значения плотности теплового 

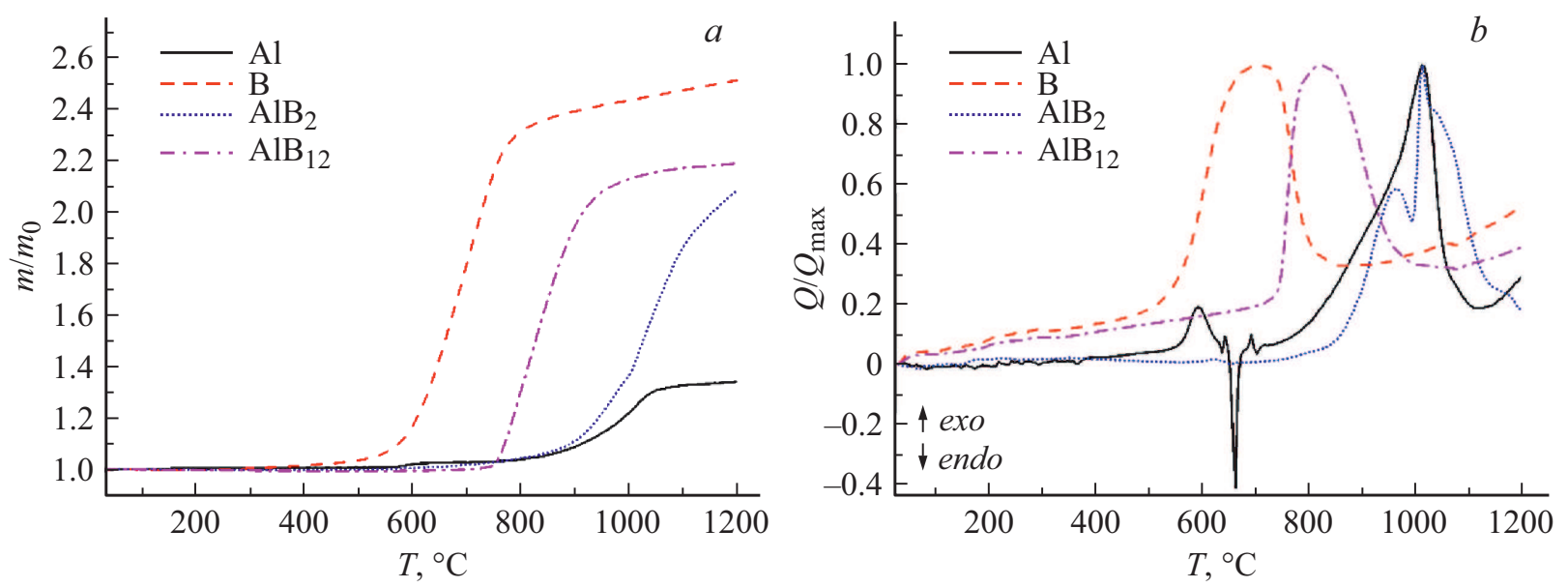

Рис. 1. Линии ТГ $(a)$ и ДСК $(b)$ анализов порошков $\mathrm{Al}, \mathrm{B}, \mathrm{AlB}_{2}$ и $\mathrm{AlB}_{12}$ при скорости нагрева $10^{\circ} \mathrm{C} / \mathrm{min}$ в воздухе.

потока, падающего на торцевую поверхность образца, в диапазоне $q=60-220 \mathrm{~W} / \mathrm{cm}^{2}$. Регулирование выходной мощности лазерного излучения осуществлялось с помощью системы управления параметров импульсов накачки и высокочастотной мощности разрядных электродов лазерной головки. Относительная погрешность разброса данных времени задержки tign составляла 5-15\% при величине доверительной вероятности 0.95 .

\section{2. Результаты и обсуждение}

\section{1. Термический анализ}

В результате проведенных термогравиметрического анализа (ТГ) и дифференциальной сканирующей калориметрии (ДСК) получены кривые изменения относительной массы (рис. $1, a$ ) и удельного теплового потока (рис. $1, b$ ) порошков $\mathrm{Al}, \mathrm{B}, \mathrm{AlB}_{2}$ и $\mathrm{AlB}_{12}$.

При нагреве образца микроразмерного порошка $\mathrm{Al}$ процесс окисления в воздухе проходит в две стадии. Первая стадия окисления протекает до начала плавления алюминия в диапазоне температур $560-640^{\circ} \mathrm{C}$ и сопровождается незначительным ростом массы навески $(\sim 2 \%)$. При температуре $660^{\circ} \mathrm{C}$ происходит эндотермическое плавление порошка алюминия (рис. 1,b), после которого в диапазоне температур 800-1060 $\mathrm{C}$ наблюдается интенсивное увеличение массы образца (до $34 \%$, вторая стадия), сопровождающееся интенсивным выделением тепла $\left(Q_{\max }=11.9 \mathrm{~W} / \mathrm{g}\right)$.

При нагреве порошков аморфного бора и боридов алюминия процесс окисления протекает одностадийно (рис. 1). Для образца порошка аморфного бора процесс интенсивного окисления проходит в интервале температур 560-800 ${ }^{\circ} \mathrm{C}$ с максимальным удельным тепловым потоком $Q_{\max }=27.7 \mathrm{~W} / \mathrm{g}$, при этом масса бора увеличивается на $140 \%$ от начальной массы навески аморфного бора (рис. 1,a). Последующий нагрев порошка бора в воздухе до температуры $1200^{\circ} \mathrm{C}$ протекает менее интенсивно с плавным увеличением массы образца на $\sim 10 \%$.

ТГ и ДСК-кривые для порошка $\mathrm{AlB}_{2}$ (рис. 1) показывают, что большое содержание алюминия в составе $\mathrm{AlB}_{2}$ (по сравнению с $\mathrm{AlB}_{12}$ или В) сдвигает процесс окисления диборида в сторону более высоких температур. Интенсивный процесс окисления порошка $\mathrm{AlB}_{2}$ проходит в диапазоне температур 880-1120 ${ }^{\circ} \mathrm{C}$ с максимальным удельным тепловым потоком $10.6 \mathrm{~W} / \mathrm{g}$, при этом прирост массы образца составляет 108\%. Наличие двух пиков на ДСК-кривой (рис. 1,b) для порошка $\mathrm{AlB}_{2}$ при температурах 960 и $1010^{\circ} \mathrm{C}$ может свидетельствовать о его нестабильности и разложении при температуре выше $900^{\circ} \mathrm{C}$ с образованием алюминия и $\mathrm{AlB}_{12}$, или образованием других фаз боридов и сплавов бора и алюминия, что отмечается авторами в $[19,20]$.

Порошок додекаборида алюминия $\mathrm{AlB}_{12}$, как и аморфный бор, имеет одностадийный процесс окисления (рис. 1), но его интенсивное окисление проходит при более высоких температурах $750-950^{\circ} \mathrm{C}$ с максимальным удельным тепловым потоком $28.9 \mathrm{~W} / \mathrm{g}$. При нагреве до $1200^{\circ} \mathrm{C}$ прирост массы образца $\mathrm{AlB}_{12}$ в воздухе составляет $118 \%$.

По экспериментальным данным ТГ-ДСК анализа для порошков металлов определены значения температуры начала интенсивного окисления $T_{\text {on}}$, прироста массы $\Delta m$, суммарного теплового эффекта реакции окисления $Q$ и скорости окисления $v_{\text {ох }}$ (табл. 2).

Среди исследуемых порошков наивысшим тепловым эффектом при окислении в воздухе обладает порошок аморфного бора с $Q=21550 \mathrm{~J} / \mathrm{g}$. Наибольшее значение скорости окисления определено для порошка $\mathrm{AlB}_{12}$, которое составляет $v_{\text {ох }}=0.624 \mu \mathrm{g} / \mathrm{min}$ в диапазоне температур $780-870^{\circ} \mathrm{C}$.

Проведенный ранее расчет кинетических параметров окисления [21] показал, что при степени конверсии (окисленности) 0.10-0.25 для порошков алюминия и диборида алюминия значения энергии активации принимают наибольшие значения $300-370 \mathrm{~kJ} / \mathrm{mol}$, а для по- 
Таблица 2. Параметры окисления порошков металлов и бора

\begin{tabular}{c|c|c|c|c}
\hline Порошок & $T_{\text {on }},{ }^{\circ} \mathrm{C}$ & $\Delta m$, mass. $\%$ & $Q, \mathrm{~J} / \mathrm{g}$ & $v_{\text {ox }}, \mathrm{mg} / \mathrm{min}\left(\right.$ в диапазоне температур, $\left.{ }^{\circ} \mathrm{C}\right)$ \\
\hline $\mathrm{Al}$ & 800 & 34 & 3680 & $0.119(970-1040)$ \\
$\mathrm{B}$ & 560 & 150 & 21550 & $0.534(650-750)$ \\
$\mathrm{AlB}_{2}$ & 880 & 108 & 5230 & $0.306(1000-1080)$ \\
$\mathrm{AlB}_{12}$ & 750 & 118 & 20270 & $0.624(780-870)$
\end{tabular}

Таблица 3. Значения констант $a$ и $b$ в уравнении аппроксимации $t_{\text {ing }}(q)=a \cdot q^{-b}$ составов ВЭМ, содержащих порошки металлов

\begin{tabular}{c|c|c|c|c|c|c|c|c|c|c|c|c}
\hline ВЭМ & $1-1$ & $1-2$ & $1-3$ & $1-4$ & $2-1$ & $2-2$ & $2-3$ & $2-4$ & $3-1$ & $3-2$ & $3-3$ & $3-4$ \\
\hline$a \cdot 10^{-4}$ & 6.92 & 2.77 & 18.3 & 58.1 & 18.7 & 14.0 & 199 & 385 & 142 & 32.1 & 10.0 & 87.4 \\
$b$ & 1.51 & 1.45 & 1.70 & 1.97 & 1.64 & 1.65 & 2.15 & 2.28 & 1.83 & 1.72 & 1.45 & 1.87
\end{tabular}

Таблица 4. Значения коэффициента $K_{\mathrm{ign}}$ составов ВЭМ в зависимости от плотности теплового потока

\begin{tabular}{|c|c|c|c|c|c|c|c|c|c|}
\hline \multirow{2}{*}{ Состав ВЭМ } & \multicolumn{9}{|c|}{$K_{\text {ign }}$} \\
\hline & 1 & 2 & 3 & 1 & 2 & 3 & 1 & 2 & 3 \\
\hline$q, \mathrm{~W} / \mathrm{cm}^{2}$ & \multicolumn{3}{|c|}{$t_{\text {ing }}^{\mathrm{Al}} / t_{\text {ing }}^{\mathrm{B}}$} & \multicolumn{3}{|c|}{$t_{\text {ing }}^{\mathrm{Al}} / t_{\text {ing }}^{\mathrm{AlB}_{2}}$} & \multicolumn{3}{|c|}{$t_{\text {ing }}^{\mathrm{Al}} / t_{\text {ing }}^{\mathrm{B}_{12}}$} \\
\hline 70 & 1.92 & 1.38 & 2.76 & 0.85 & 0.80 & 2.75 & 0.84 & 0.73 & 1.93 \\
\hline 110 & 1.87 & 1.39 & 2.63 & 0.93 & 1.01 & 2.31 & 1.03 & 0.98 & 1.96 \\
\hline 150 & 1.83 & 1.39 & 2.54 & 0.98 & 1.18 & 2.05 & 1.19 & 1.19 & 1.99 \\
\hline 210 & 1.80 & 1.39 & 2.45 & 1.05 & 1.40 & 1.80 & 1.39 & 1.48 & 2.02 \\
\hline
\end{tabular}

рошков бора и додекаборида алюминия при одинаковом значении степени конверсии значение энергии активации меняется в пределах 50-200 kJ/mol. Энергия активации окисления для порошка $\mathrm{Al}$ в интервале степени конверсии 0.4-0.8 значительно выше (300-450 kJ/mol), чем значения энергии активации для аморфного бора, $\mathrm{AlB}_{2}$ и $\mathrm{AlB}_{12}$, которые лежат в диапазоне значений $120-350,200-250$ и $50-90 \mathrm{~kJ} / \mathrm{mol}$ соответственно.

В диапазоне степени конверсии 0.2-0.8 порошок додекаборида алюминия $\mathrm{AlB}_{12}$ имеет наименьшие значения энергии активации окисления по сравнению со значениями для порошков $\mathrm{Al}, \mathrm{B}$ и $\mathrm{AlB}_{2}$. Однако при степени конверсии $0.1-0.2$, которая в большей степени характеризует процесс зажигания порошков, для $\mathrm{AlB}_{12}$ значение энергии активации ниже, чем для порошка бора.

\section{2. Время задержки зажигания}

Для исследуемых составов ВЭМ, содержащих порошки металлов, определены значения времени задержки зажигания образцов в зависимости от плотности теплового потока при инициировании лазерным импульсом. Результаты измерения представлены в виде точек на рис. 2. Кадры скоростной видеосъемки процесса зажигания состава 3 ВЭМ, содержащего ПХА, НА и МПВТ-АСП, при инициировании лучистым потоком тепла плотностью $q=68 \mathrm{~W} / \mathrm{cm}^{2}$ представлены на рис. 3 .
Расчетные значения параметров аппроксимации степенной зависимости $t_{\text {ign }}(q)$ и коэффициента $K_{\text {ign }}$, равного отношению времени задержки зажигания состава ВЭМ, содержащего Al, ко времени задержки зажигания ВЭМ, содержащего $\mathrm{B}, \mathrm{AlB}_{2}$ и $\mathrm{AlB}_{12}$, представлены в табл. 3 и 4.

Анализ полученных экспериментальных данных показал, что наименышие значения времени задержки зажигания ВЭМ зафиксированы для состава 1 на основе ПХА/СКДМ-80/Mе, а наибольшие значения для состава 3 на основе ПХА/НА/МПВТ-АСП/Ме при одинаковых условиях зажигания и содержании металлического горючего. Время задержки зажигания состава 11 , содержащего чистый $\mathrm{Al}$, в 3.0-4.1 раза меньше по сравнению со значением tign состава 3-1 (рис. 2,a), т. е. применение активного горючего-связующего в ВЭМ значительно увеличивает период прогрева и зажигания топлива по сравнению с ВЭМ на основе инертного связующего. При замене чистого ПХА (состав 1-1) на смесь окислителей ПХА/НА (состав 2-1) в составе ВЭМ на основе инертного связующего СКДМ-80 времена $t_{\text {ing }}$ увеличиваются в 1.1-1.7 раза при одинаковых условиях зажигания.

В случае замены порошка Al на аморфный бор во всех исследуемых составах ВЭМ времена задержки зажигания уменьшаются во всем диапазоне $q$. При этом отношение $t_{\text {ing }}$ состава 3-2 на основе ПХА/НА/МПВТ к $t_{\text {ing }}$ состава 1-2 на основе ПХА/СКДМ-80, содержащего чистый $\mathrm{B}$, составляет 2.5-2.9 в зависимости от 

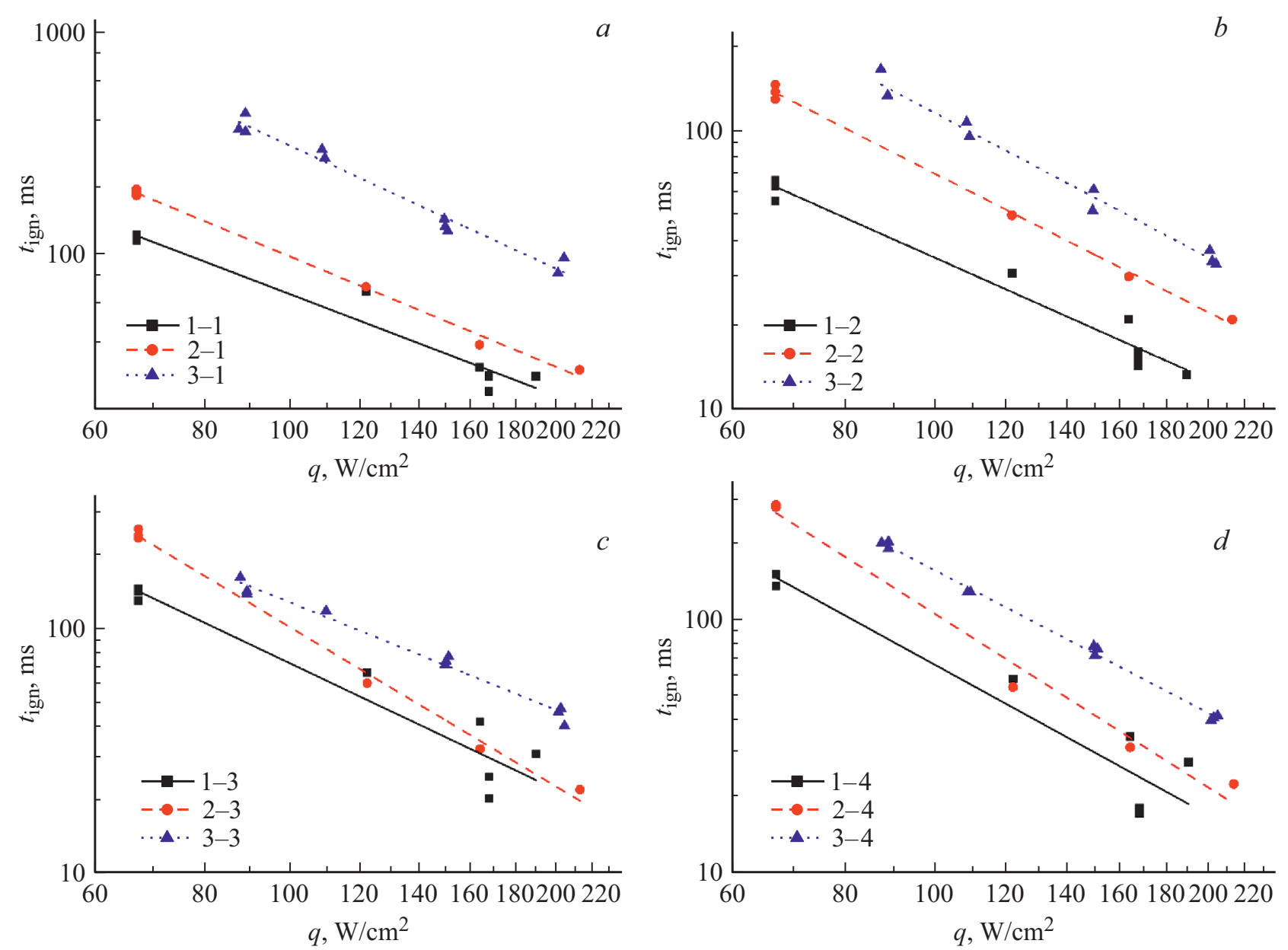

Рис. 2. Время задержки зажигания образца в зависимости от плотности теплового потока для составов ВЭМ: $a-1-1,2-1,3-1$ с $\mathrm{Al} ; b-1-2,2-2,3-2$ c B; $c-1-3,2-3,3-3$ с AlB $2 ; d-1-4,2-4,3-4$ с $\mathrm{AlB}_{12}$.

значений $q$ (рис. $2, b$ ). Отношение $t_{\text {ing }}$ состава $2-2$ на основе ПХА/НА/СКДМ-80 к $t_{\text {ing }}$ состава $1-2$ на основе ПХА/СКДМ-80, содержащего бор, составляет 1.4-2.1.

В случае использования диборида алюминия $\mathrm{AlB}_{2}$ в составе 1-3 на основе ПХА/СКДМ-80 значения $t_{\text {ing }}$ снижаются в $1.2-1.9$ раза и в $1.4-1.8$ раза, по сравнению с $t_{\text {ing }}$ составов 2-3 и 3-3 на основе ПХА/НА/СКДМ-80 и ПХА/НА/МПВТ соответственно (рис. 2,c). Типичная ситуация наблюдается для составов ВЭМ 1-4, 2-4 и 3-4, содержащих додекаборид алюминия $\mathrm{AlB}_{12}$ (рис. 2,d).

В составах ВЭМ на основе бутадиенового каучука СКДМ-80, ПХА или ПХА/НА (составы 1 и 2) при замене $\mathrm{Al}$ на бориды алюминия $\mathrm{AlB}_{2}$ и $\mathrm{AlB}_{12}$ времена задержки зажигания $t_{\text {ing }}$ увеличиваются на $2-20 \%$ при значениях плотности теплового потока $q \leq 110 \mathrm{~W} / \mathrm{cm}^{2}$ (табл. 3). При значениях $q>160 \mathrm{~W} / \mathrm{cm}^{2}$ времена задержки зажигания указанных составов ВЭМ снижаются. Отметим, что при использовании аморфного бора в составах 1 и 2 ВЭМ на основе СКДМ-80 времена задержки зажигания снижаются в 1.9 и 1.4 раза соответственно во всем диапазоне плотности теплового потока.
При использовании боридов алюминия $\mathrm{AlB}_{2}$ и $\mathrm{AlB}_{12}$ в составе 3 ВЭМ на основе активного горючегосвязующего и ПХА/НА времена задержки зажигания образцов значительно снижаются в $1.8-2.8$ раза в зависимости от значений $q$ по сравнению с ВЭМ, содержащим чистый $\mathrm{Al}$.

Согласно полученным данным тепловизионной съемки, в момент оттока продуктов разложения с поверхности образца топлива и появления пламени наблюдается резкое увеличение температуры по всей площади торцевой поверхности и скорости оттока продуктов разложения, что обусловлено дополнительным подводом тепла из зоны химических реакций в газовой фазе. Продукты разложения с поверхности реакционного слоя увлекают за собой частицы порошка, что вносит дополнительный приток тепла за счет экзотермического окисления металлических частиц. Отметим, что для состава ВЭМ, содержащего чистый алюминий, период прогрева и формирования реакционного слоя топлива достаточно длительный по сравнению с другими составами ВЭМ, содержащими бор или бориды алюминия, и основная доля подводимого тепла от источника излуче- 

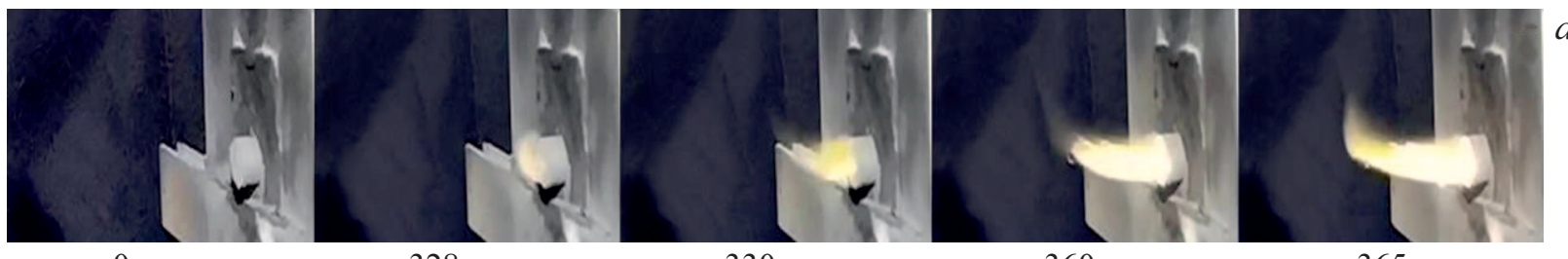

$\sim 0 \mathrm{~ms}$

$\sim 328 \mathrm{~ms}$

$\sim 330 \mathrm{~ms}$

$\sim 360 \mathrm{~ms}$

$\sim 365 \mathrm{~ms}$

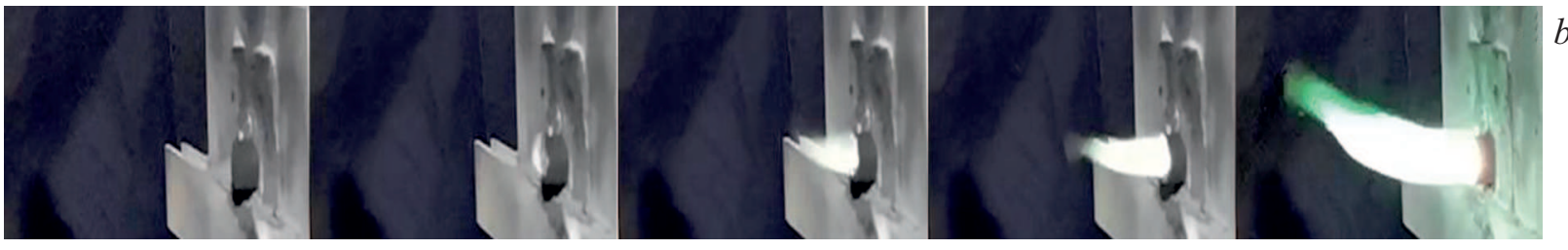

$\sim 0 \mathrm{~ms}$

$\sim 206 \mathrm{~ms}$

$\sim 208 \mathrm{~ms}$

$\sim 209 \mathrm{~ms}$

$\sim 211 \mathrm{~ms}$

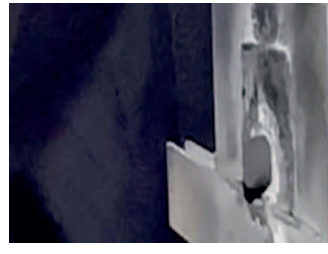

$\sim 0 \mathrm{~ms}$

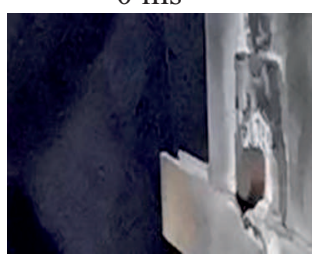

$\sim 0 \mathrm{~ms}$

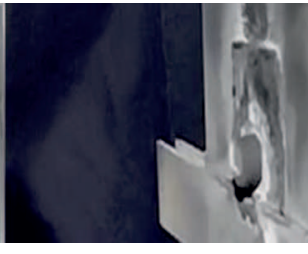

$\sim 289 \mathrm{~ms}$

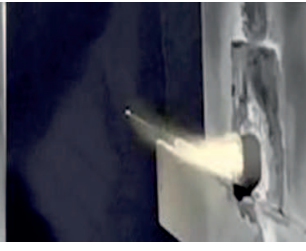

$\sim 292 \mathrm{~ms}$

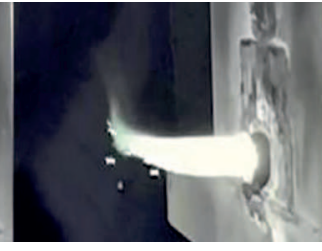

$\sim 300 \mathrm{~ms}$

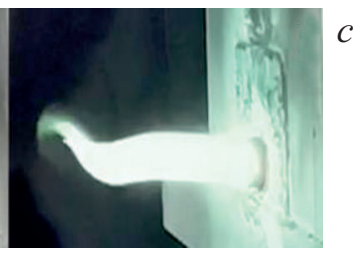

$\sim 336 \mathrm{~ms}$

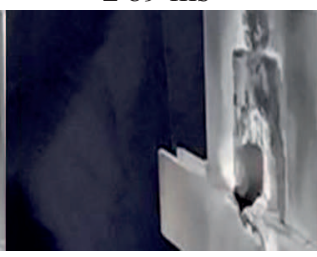

$\sim 357 \mathrm{~ms}$

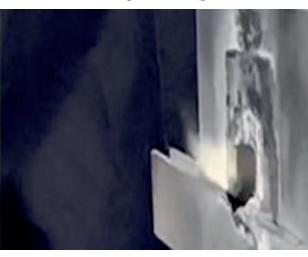

$\sim 358 \mathrm{~ms}$

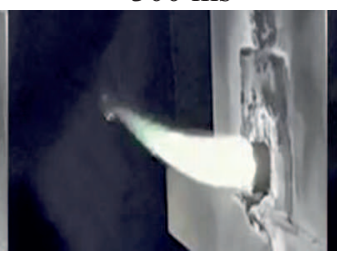

$\sim 362 \mathrm{~ms}$

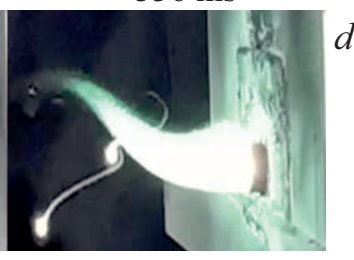

$\sim 365 \mathrm{~ms}$

Рис. 3. Кадры скоростной видеосъемки зажигания состава ВЭМ на основе ПХА/НА/МПВТ-АСП, содержащего: $a-\mathrm{Al} ; b-\mathrm{B}$; $c-\mathrm{AlB}_{2} ; d-\mathrm{AlB}_{12}$ при $q=68 \mathrm{~W} / \mathrm{cm}^{2}$.

ния идет на кондуктивный прогрев поверхностного слоя, разложение компонентов и плавление частиц алюминия, находящихся вблизи поверхности образца. Наличие значительной доли крупных частиц в составе порошка $\mathrm{Al}$ и огнеупорного оксидного слоя на его поверхности увеличивает температуру начала интенсивного окисления в сравнении с аморфным бором или $\mathrm{AlB}_{12}$, что приводит к снижению устойчивости зажигания образца и доли выделяемого тепла при окислении частиц вблизи поверхности топлива. Кроме того, предполагается, что порошок бора увеличивает поглощательную способность поверхности топлива и тем самым снижает время задержки зажигания ВЭМ.

\section{Заключение}

Получены экспериментальные данные ТГ/ДСК анализа микроразмерных порошков алюминия, бора и боридов алюминия при нагреве их в воздухе 30 до $1200^{\circ} \mathrm{C}$. На основе данных термического анализа определены значения температуры начала окисления, прироста массы образца, теплового эффекта реакции окисления и максимальной скорости окисления порошков металла и бора. Окисление порошка алюминия протекает в две стадии, при этом первая стадия окисления не играет существенной роли (прирост массы навески составляет $\sim 2 \%$ ) и проходит ниже температуры плавления алюминия. Основной процесс окисления алюминия протекает в диапазоне температур $800-1060^{\circ} \mathrm{C}$. Для порошков бора и боридов алюминия окисление проходит в одну стадию. Отметим, что для порошка диборида алюминия наблюдается незначительный эндотермический пик, который связан с процессом разложения $\mathrm{AlB}_{2}$ и образованием других фаз боридов и сплавов бора с алюминием, при значениях температур воздуха 965 и $1013^{\circ} \mathrm{C}$.

Наибольшим тепловым эффектом реакции окисления обладают порошки аморфного бора и додекаборида алюминия (21.6 и $20.3 \mathrm{~kJ} / \mathrm{g}$ соответственно), значения которых значительно превосходят значения теплового эффекта порошка $\mathrm{Al}(3.7 \mathrm{~kJ} / \mathrm{g})$ и $\mathrm{AlB}_{2}(5.2 \mathrm{~kJ} / \mathrm{g})$. При этом максимальной скоростью окисления обладает порошок $\mathrm{AlB}_{12}$, значения которой на $15 \%$ выше скорости окисления В, и в 2.0 и 5.2 раза больше, чем у порошков $\mathrm{AlB}_{2}$ и $\mathrm{Al}$.

Результаты экспериментального исследования процесса зажигания составов ВЭМ, содержащих порошки Al, $\mathrm{B}, \mathrm{AlB}_{2}$ или $\mathrm{AlB}_{12}$, показали, что при использовании в составах ВЭМ двойного окислителя ПХА/НА и 
активного горючего-связующего МПВТ-АСП времена прогрева и задержки зажигания увеличиваются по сравнению с ВЭМ на основе ПХА и бутадиенового каучука СКДМ-80.

При замещении микронного алюминия на аморфный бор времена задержки зажигания снижаются для всех рассматриваемых составов ВЭМ. Наибольшая эффективность замены $\mathrm{Al}$ на бориды алюминия $\mathrm{AlB}_{2}$ и $\mathrm{AlB}_{12}$ обнаружена для состава ВЭМ на основе двойного окислителя и активного связующего (ПХА/НА/МПВТ-АСП), в результате которого увеличивается устойчивость зажигания и снижается время задержки зажигания в $1.8-2.8$ раза при одинаковых значениях плотности теплового потока. При использовании $\mathrm{AlB}_{2}$ и $\mathrm{AlB}_{12}$ в составах ВЭМ на основе инертного связующего (ПХА/СКДМ-80 и ПХА/НА/СКДМ-80) времена прогрева и задержки зажигания топлив снижаются при плотности теплового потока $q>160 \mathrm{~W} / \mathrm{cm}^{2}$.

\section{Финансирование работы}

Исследование выполнено при финансовой поддержке РФФИ, проект № 20-03-00588.

\section{Конфликт интересов}

Авторы заявляют, что у них нет конфликта интересов.

\section{Список литературы}

[1] E.L. Dreizin. Prog. Energ. Combust., 35 (2), 141 (2009). DOI: 10.1016/j.pecs.2008.09.001

[2] A. Gromov, L.T. Deluca, A.P. Il'in, U. Teipel, A. Petrova, D. Prokopiev. Int. J. Energ. Mater. Chem. Propul., 13 (5), 399 (2014). DOI: 10.1615/IntJEnergeticMaterialsChemProp.2014011255

[3] Л.С. Яновский. Энергоемкие горючие для авиационных и ракетных двигателей (Физматлит, М., 2009), с. 400.

[4] Д.С. Сандарам, В. Янг, В.Е. Зарко. ФГВ, 51 (2), 37 (2015).

[5] Y. Sun, K.L. Chintersingh, M. Schoenitz, E.L. Dreizin. J. Phys. Chem. C, 123 (18), 11807 (2019). DOI: $10.1021 /$ acs.jpcc.9b03363

[6] X. Liu, J. Gonzales, M. Schoenitz, E.L. Dreizin. Thermochim. Acta, 652, 17 (2017).

[7] D. Yu, C. Kong, J.-K. Zhuo, S.Q. Li, Q. Yao. Sci. China Technol. Sci., $58(12), 2016$ (2015). DOI: $10.1007 / \mathrm{s} 11431-015-5841-0$

[8] V. Arkhipov, L. Savelieva, P. Ponomarev. MATEC Web Conf. 110, 01075 (2017). DOI: 10.1051/matecconf/201711001075

[9] В.А. Архипов, А.С. Жуков, В.Т. Кузнецов, Н.Н. Золотарев, Н.А. Осипова, К.Г. Перфильева. ФГВ, 54 (6), 68 (2018). DOI: $10.15372 / \mathrm{FGV} 20180608$

[10] А.Г. Коротких, В.А. Архипов, И.В. Сорокин, Е.А. Селихова. Хим. физ. мезоскопия, 20 (1), 5 (2018).

[11] M.L. Whittaker, R.A. Cutler, P.E. Anderson. MRS Symp. Proc., 1405, 96 (2011). DOI: 10.1557/opl.2012.64

[12] D. Liang, R. Xiao, J. Liu, Y. Wang. Aerospace Sci. Technol., 84, 1081 (2019).

[13] S. Adil, B.S. Murty. Thermochim. Acta, 678, 178306 (2019).
[14] M.L. Whittaker, H.Y. Sohn, R.A. Cutler. J. Solid State Chem., 207, 163 (2013).

[15] I. Zhukov, A. Vorozhtsov, V. Promakhov, Y. Dubkova, A. Zhukov, A. Khrustalev. MATEC Web Conf. 243 (00015), 1 (2018). DOI: 10.1051/matecconf/201824300015

[16] Д.А. Ягодников, А.В. Воронецкий, В.И. Сарабьев. ФГВ, $52(3), 51$ (2016).

[17] В.В. Промахов, М.Х. Зиатдинов, И.А. Жуков, С.А. Ворожцов, А.Е. Матвеев, С.С. Титов. Ползуновский вестник, 1 (4), 76 (2016).

[18] И.А. Жуков, М.Х. Зиатдинов, А.Б. Ворожцов, А.С. Жуков, С.А. Ворожцов, В.В. Промахов. Изв. вузов. Физика, 59 (8), 177 (2016). [I.A. Zhukov, M.K. Ziatdinov, A.B. Vorozhtsov, A.S. Zhukov, S.A. Vorozhtsov, V.V. Promakhov. Russ. Phys. J. 59 (8), 1324 (2016). DOI: 10.1007/s11182-016-0911-8]

[19] Ш.Л. Гусейнов, С.Г. Федоров, А.Ю. Тузов, С.И. Малашин, А.И. Драчев, М.Р. Киселев, Б.В. Певченко, О.В. Воронько. Российские нанотехнологии, 10 (5-6), 79 (2015). [S.L. Guseinov, S.G. Fedorov, A.Y. Tuzov, S.I. Malashin, A.I. Drachev, M.R. Kisilev, B.V. Pevchenko, O.V. Voron'ko. Nanotechnol. Russ., 10 (5-6), 420 (2015). DOI: $10.1134 / \mathrm{S} 199507801503009 \mathrm{X}]$

[20] Н.В. Кириллова, А.И. Харламов, С.В. Лойченко. Неорг. матер., 36 (8), 937 (2000). [N.V. Kirillova, A.I. Kharlamov, S.V. Loichenko. Inorg. Mater., 36 (8), 776 (2000). DOI: $10.1007 / \mathrm{BF} 02758596]$

[21] А.Г. Коротких, К.В. Слюсарский, И.В. Сорокин. Хим. физ. мезоскопия, 22 (2), 164 (2020). DOI: $10.15350 / 17270529.2020 .2 .16$ 